\title{
Stand-Alone Hybrid Generation System Based on Renewable Energy
}

\author{
Hung-Cheng Chen, Po-Hung Chen, Long-Yi Chang, and Wei-Xin Bai
}

\begin{abstract}
This paper presents the dynamic modeling and the simulation results of a renewable energy based hybrid power generation system. In order to meet sustained load demands during varying natural conditions, different renewable energy sources need to be integrated with each other. The paper focuses on the combination of solar cell (SC), wind turbine (WT), hydro turbine (HT), fuel cell (FC) and vanadium redox flow battery (VRB) systems for power generation. As the wind turbine output power varies with the wind speed, the hydro turbine output power with the water speed and the solar cell output power with both the ambient temperature and radiation, a FC system with an UC bank and a VRB system can be integrated to store excess wind, hydro and solar energies under all conditions. Dynamic modeling of various components of this isolated system is presented. Transient responses of the system to step changes in the load, ambient temperature, radiation, wind speed and water speed in a number of possible situations are studied. The results show that the proposed hybrid power system can tolerate the rapid changes in natural conditions and suppress the effects of these fluctuations on the voltage within the acceptable range.
\end{abstract}

Index Terms-Hydro turbine, wind turbine, vanadium redox flow battery, fuel cell, hybrid generation system.

\section{INTRODUCTION}

The fossil fuel will produce pollution after burning, such as carbon dioxide, nitrogen oxide, sulfur oxide compound and the carbon hydrogen compound etc [1]. All of these poisonous airs are the cause of the air pollutions and green house effects. The fossil fuel is the non-renewable resources and less and less after massive consumptions. Comparing with the nuclear energy and thermal power, the renewable energy is inexhaustible and has non-pollution characteristics. The solar energy, wind power, hydro power and tide energy are natural resources of the interest to generate electrical sources. An unique hydro resources in Taiwan is irrigation water in agriculture canals and some countries like Japan and India also use the irrigation water in an agriculture canal [2], [3]. In Japan had been use the irrigation water in agriculture canals by water current speed and this form of generation don't need high water head [3].

The wind, hydro and solar energy are welcome substitution for many other energy resources because it is

Manuscript received April 1, 2013; revised June 1, 2013. This work was supported in part by the National Science Council, Taiwan, Republic of China, under Grant No. NSC 101-ET-E-167-00-ET.

H. C. Chen is with the Electrical engineering Department, National Chin-Yi University of Technology, Taichung, 41107 Taiwan (e-mail: hchen@ncut.edu.tw).

P. H. Chen is with the Electrical Engineering Department, St. John's University, Taipei, 25135 Taiwan (e-mail: phchen@mail.sju.edu.tw). natural, inexhaustible resource of sunlight to generate electricity [4].The renewable energy generation had a significant problem is to store the energy generated for future usage when no wind is available but the user demand exists [4]. For this problem can be solving by energy storage system. The energy storage systems can be classified as $\mathrm{Cr}-\mathrm{Fe}, \mathrm{Cd}-\mathrm{Ni}$, lead-acid and vanadium redox flow batteries. The VRB is deemed as a promising green solution in practical applications [5], due to the advantages of large scale, simple structure, long life cycle and high SOC. After many technological advances, proton exchange membrane fuel cell technology has now reached the test and demonstration phase. The recent commercial availability of small PEMFC units has created many new opportunities to design hybrid energy systems for remote applications with energy storage in hydrogen form [6].

In this paper, a detailed dynamic model and simulation of a solar cell/wind turbine/hydro turbine/fuel cell/vanadium redox flow battery hybrid power system is developed using a novel topology to complement each other and to alleviate the effects of environmental variations. Modeling and simulations are conducted using MATLAB/Simulink software packages to verify the effectiveness of the proposed system. The results show that the proposed hybrid power system can tolerate the rapid changes in natural conditions and suppress the effects of these fluctuations on the voltage within the acceptable range.

\section{DynAmiC SySTEM Models}

\section{A. Solar Cell}

A solar cell module consists of many jointly connected solar cells. A number of solar cell models have been developed, but the one diode electrical equivalent circuit shown in Fig. 1(a) is commonly used for cell based or module based analysis. It consists of a diode, a current source, a series resistance and a parallel resistance. The current source generates the photo-current that is a function of the incident solar cell radiation and temperature [7]-[9]. The diode represents the $\mathrm{p}-\mathrm{n}$ junction of a solar cell. The temperature dependence of the diode saturation current and constant diode ideality factor are included in the modeling. At real solar cells, a voltage loss on the way to the external contacts is observed. This voltage loss is expressed by a series resistance $\left(\mathrm{R}_{\mathrm{s}}\right)$. Furthermore leakage currents are described by a parallel resistance $\left(\mathrm{R}_{\mathrm{sh}}\right)$. However, the series resistance is very small and the parallel resistance is very large [9]. So we can ignore $R_{s}$ and $R_{s h}$. The solar cell simplified circuit is then shown in Fig. 1(b). 


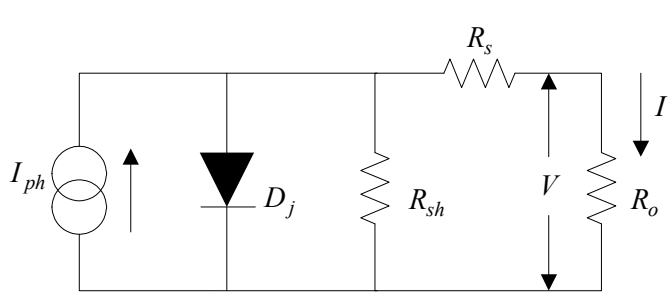

(a)

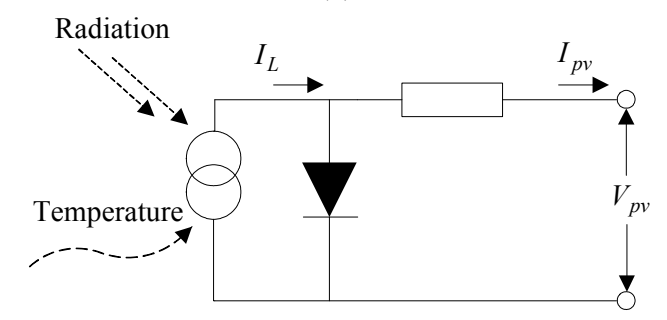

(b)

Fig. 1. Solar cell (a) equivalent circuit(b) simplified circuit.

The solar cell current equation is

$$
\begin{gathered}
I_{p v}(t)=I_{s c}\left\{1-C_{1}\left[\exp \left(\frac{V_{m p}}{C_{2} V_{o c}}\right)-1\right]\right\} \\
+\left(\frac{E_{t t}(t)}{E_{s t}}\right)\left[\alpha\left(T_{a}(t)+0.002 E_{t t}(t)+1\right)\right]-I_{m p}
\end{gathered}
$$

The solar cell voltage equation is

$$
\begin{gathered}
V_{p v}(t)=V_{m p}\left[1+0.0539 \log \left(\frac{E_{t t}(t)}{E_{s t}}\right)\right] \\
+\beta\left(T_{a}(t)+0.02 E_{t t}(t)\right) \\
C_{1}=\left(1-\frac{I_{m p}}{I_{s c}}\right) \exp \left[\frac{-V_{m p}}{C_{2} V_{o c}}\right] \\
C_{2}=\frac{\frac{V_{m p}}{V_{o c}}-1}{\ln \left(1-\frac{I_{m p}}{I_{s c}}\right)}
\end{gathered}
$$

We used the solar cell current and voltage equation to build a solar cell model. The solar cell subsystem model is shown in Fig. 2.

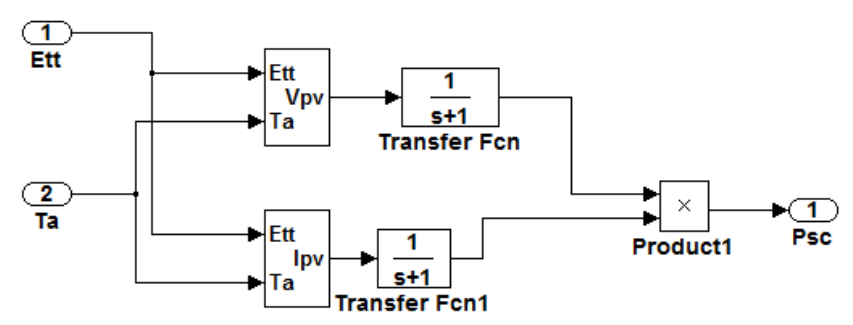

Fig. 2. Solar cell subsystem model.

\section{B. Wind Turbine}

The power output of wind turbine is relating to wind speed with a cubic ratio. The power curve of the wind turbine WE-CXF-600 studied is nonlinear, which is digitized and the resulting table is used for simulation as Fig. 3.The dynamics of the wind turbine due to its rotor inertia and generator are added by considering the wind turbine response as a second order slightly under-damped system [7], [10]. Using this simple approach, small wind turbine dynamic is modeled as

$$
P_{g}(s) / P_{w t}(s)=0.25 /\left(s^{2}+0.707 s+0.25\right)
$$

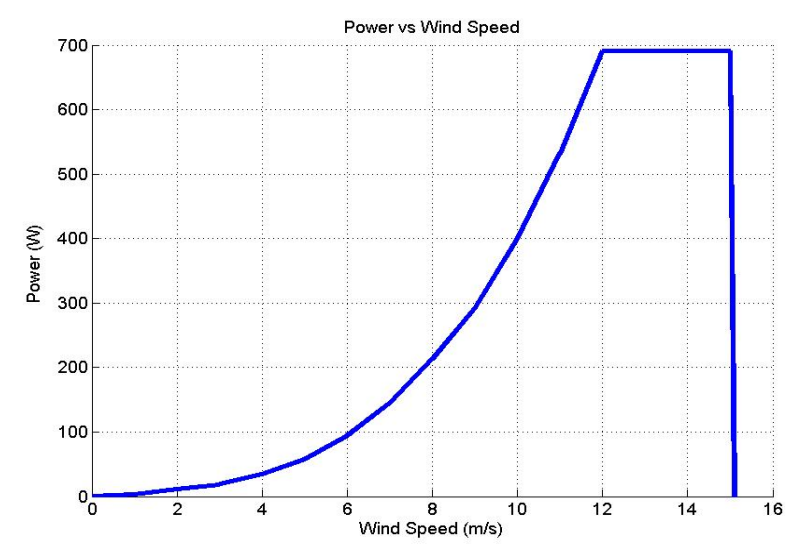

Fig. 3. WE-CXF-600 power curve.

Using (5) and Fig. 3, the wind turbine subsystem model is shown in Fig. 4.

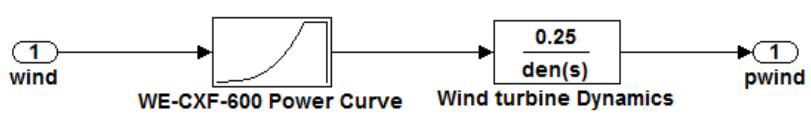

Fig. 4. Wind turbine subsystem model.

\section{Hydro Turbine}

The hydro turbine is similar to wind turbine [11], because that have same principle to extract kinetic energy to electricity. Thus, the power output of hydro turbine is relating to water current speed with a cubic ratio. The power curve of the river turbine EMC-005-F4 studied is nonlinear, which is digitized and the resulting table is used for simulation as Fig. 5. The dynamics of the hydro turbine due to its rotor inertia and generator are used by considering the hydro turbine response as a second order slightly under-damped system [12]. Because it likes wind turbine, so we used the same approach, small hydro turbine dynamic is modeled as

$$
P_{g}(s) / P_{h t}(s)=90.23 /\left(s^{2}+11.22 s+90.23\right)
$$

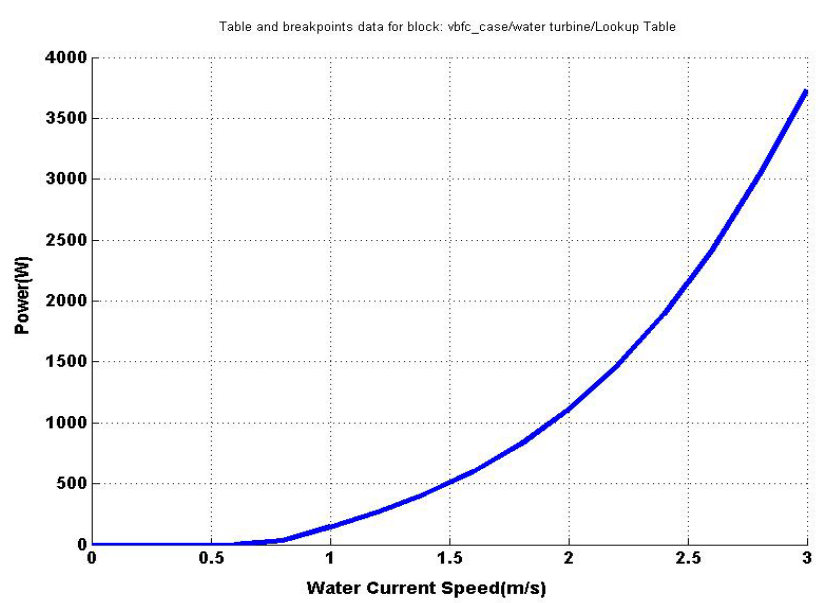

Fig. 5. ENC-005-F4 power curve. 
Using (6) and Fig. 5, the wind turbine subsystem model is shown in Fig. 6.

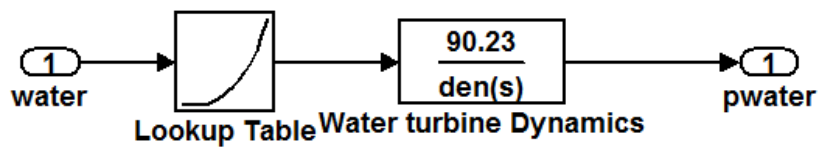

Fig. 6. Wind turbine subsystem model.

\section{Fuel Cell}

A fuel cell is a stationary power generator. The fuel cell chosen for this type of application must provide competitive, reliable, and quality power without emitting pollutants such as oxides of nitrogen, carbon or sulphur. It must respond quickly to changes in load and have low maintenance requirements as well as a long cell life [13]. The PEM fuel cell consists of porous carbon electrodes bonded to a very thin sulphonated polymer membrane. As illustrated in Fig. 7, this membrane electrode assembly (MEA) is sandwiched between two collector plates, which provide an electrical path from the electrodes to the external circuit [14]-[16]. Flow channels cut into the collector plates distribute reactant gases over the surface of the electrodes. Individual cells consisting of collector plates and MEAs are assembled in series to form a fuel cell stack [16].

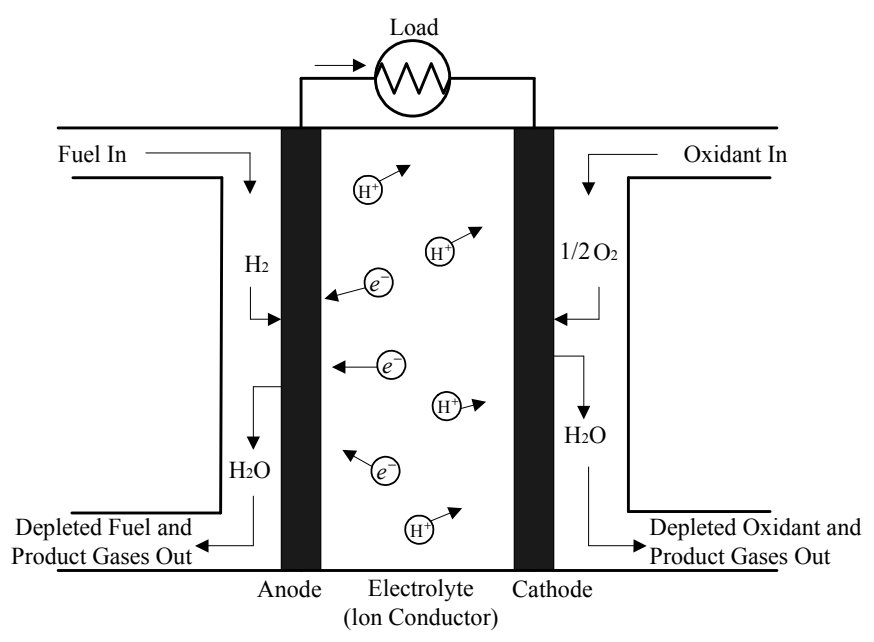

Fig. 7. PEM fuel cell diagram [14].

The thermodynamic potential $E$ is defined via a Nernst equation in expanded form as [8]

$$
\begin{gathered}
E=1.229-0.85 \times 10^{-3}(T-298.15) \\
+4.3085 \times 10^{-5} \cdot T \cdot\left(\ln P_{H_{2}}+0.5 \ln P_{O_{2}}\right)
\end{gathered}
$$

The parametric equation for the over-voltage due to activation and internal resistance developed from the empirical analysis is given as

$$
\begin{gathered}
\eta_{a c t}=-0.9514+0.00312 T-0.000187 T \ln (i) \\
+7.4 \times 10^{-5} T \ln \left(\mathrm{co}_{2}\right)
\end{gathered}
$$

$$
c o_{2}=\frac{P_{o_{2}}}{5.08 \times 10^{6} e^{\frac{-498}{t}}}
$$

$$
R_{\text {int }}=0.01605-3.5 \times 10^{-5} T+8 \times 10^{-5} i
$$

The combined effect of thermodynamics, mass transport, kinetics, and ohmic resistance determines the output voltage of the cell as defined by

$$
V_{\text {cell }}=E-v_{\text {act }}-\eta_{\text {ohmic }}
$$

The fuel cell system consists of a stack of 65 similar cells connected in series. Therefore, the total stack voltage is given by

$$
V_{\text {stack }}=65 V_{\text {cell }}
$$

Using the mole conservation principle, the gas pressure of the fuel cell anode is given as

$$
\frac{V_{a}}{R T} \frac{d P_{H_{2}}}{d t}=\dot{m}_{H_{2} \text { in }}-\left(\rho_{H_{2}} U A\right)_{o u t}-\frac{i}{2 F}
$$

The gas pressure of the fuel cell cathode is given as

$$
\frac{V_{c}}{R T} \frac{d P_{O_{2}}}{d t}=\dot{m}_{O_{2} i n}-\left(\rho_{O_{2}} U A\right)_{o u t}-\frac{i}{4 F}
$$

By (7)-(14), the MATLAB/Simulink model of a fuel cell is illustrated in Fig. 8.

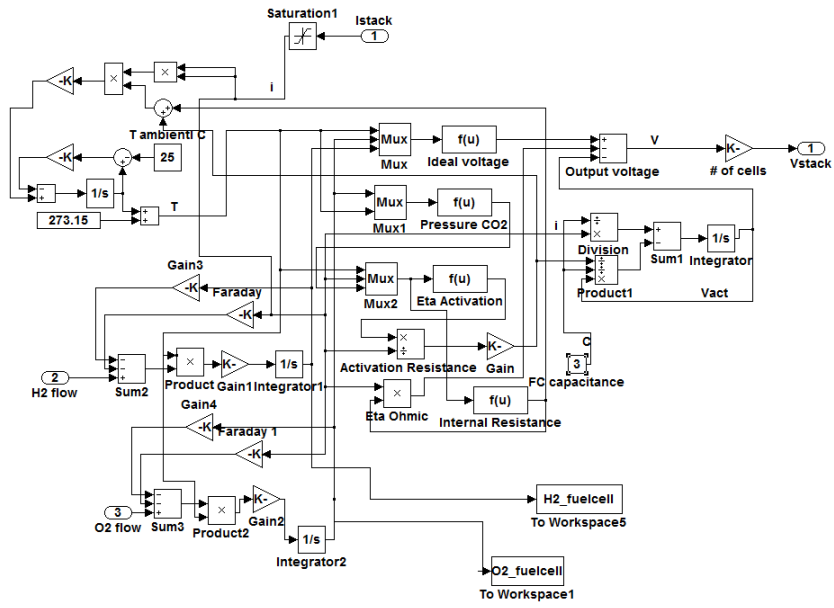

Fig. 8. Fuel cell subsystem model.

\section{E. Electrolyzer}

Water can be decomposed into its elementary components by passing electric current between two electrodes separated by an aqueous electrolyte [17], [18]. The electrochemical reaction of water electrolysis is given by

$$
\mathrm{H}_{2} \mathrm{O}(l)+\text { electrical energy } \Rightarrow \mathrm{H}_{2}(\mathrm{~g})+1 / 2 \mathrm{O}_{2}(\mathrm{~g})
$$

According to Faraday's law, hydrogen production rate of an electrolyzer cell is directly proportional to the electrical current in the equivalent electrolyzer circuit [8].

$$
n_{H_{2}}=\frac{\eta_{F} n_{c} i_{e}}{2 F}
$$

where $i_{e}$ is the electrolyzer current, $n_{c}$ is the number of electrolyzer cells in series, and $\eta_{F}$ is the Faraday efficiency. Assuming that the working temperature of the electrolyzer is $40{ }^{\circ} \mathrm{C}$, Faraday efficiency is expressed by [8], [17] 


$$
\eta_{F}=96.5 e^{\left(0.09 / i_{e}-75.5 / i_{e}^{2}\right)}
$$

By (16) and (17), a simple electrolyzer model is developed using Simulink, which is illustrated in Fig. 9.

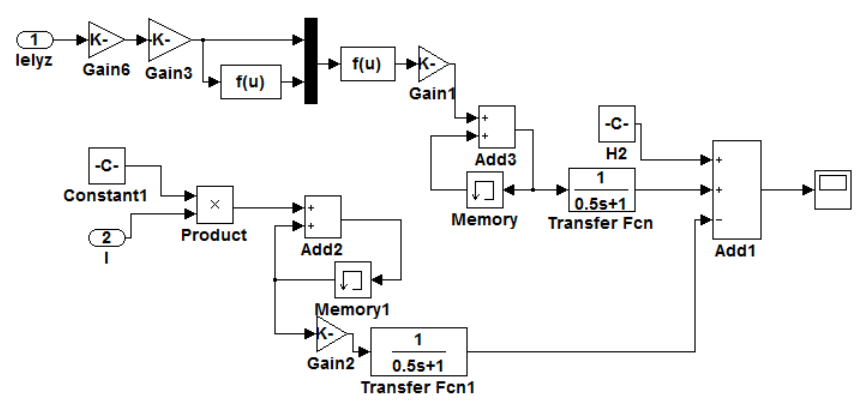

Fig. 9. Electrolyzer subsystem model.

\section{F. Vanadium Redox Flow Battery}

A VRB is an electrochemical energy storage device that employs vanadium solution as activated materials on both anode and cathode. An open circuit voltage up to $1.5 \mathrm{~V}$ is achieved in a fully charge condition. Vanadium exhibits a number of oxidation states, i.e. $\mathrm{V}^{2+}, \mathrm{V}^{3+}, \mathrm{V}^{4+}$ and $\mathrm{V}^{5+}$, but both $\mathrm{V}^{4+}$ and $\mathrm{V}^{5+}$ are essentially the vanadium oxides $\mathrm{VO}^{2+}$ and $\mathrm{VO}_{2}{ }^{+}$respectively [19]. Illustrated in Fig. 10 is a redox schematic diagram of VRB charge/discharge processes.

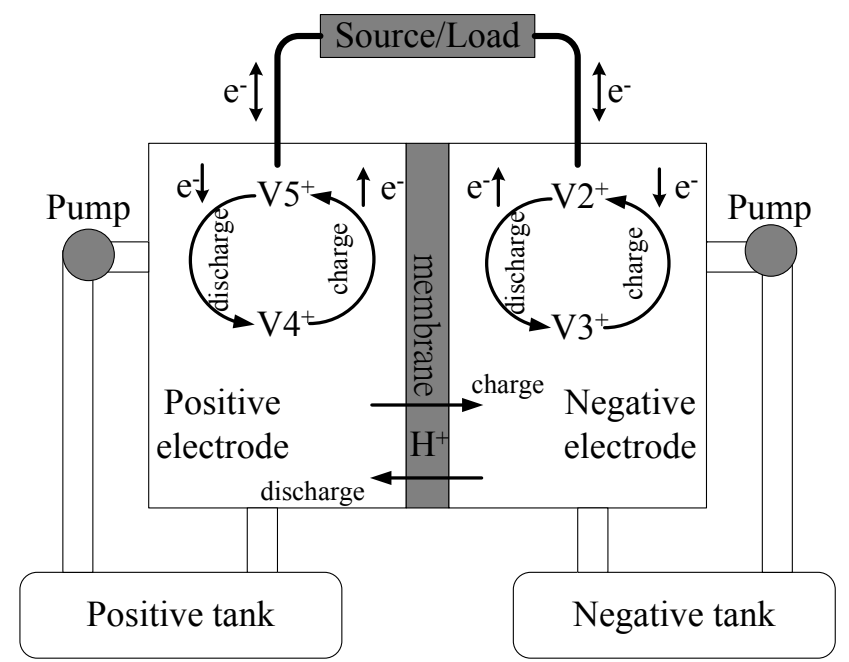

Fig. 10. Redox schematic diagram of charge/discharge of VRB.

In the discharge process, vanadium $\mathrm{V}^{5+}$ in the anolyte and $\mathrm{V}^{2+}$ in the catholyte turn into $\mathrm{V}^{4+}$ and $\mathrm{V}^{3+}$ respectively, while electrons e- migrate from the cathode toward the anode through an external load, and protons $\mathrm{H}^{+}$flow the other way around through an internal membrane. Yet, during the charge process, the same type of particles migrates in exactly the opposite direction to that in the discharge process. All the above chemical mechanism are formulated as

$$
\begin{aligned}
\mathrm{VO}_{2}{ }^{+}+2 \mathrm{H}^{+}+\mathrm{e}^{-} \stackrel{\text { discharge }}{\stackrel{\text { charge }}{\longleftarrow}} \mathrm{VO}^{2+}+\mathrm{H}_{2} \mathrm{O} \\
\mathrm{V}^{2+} \stackrel{\text { discharge }}{\stackrel{\text { charge }}{\longleftarrow}} \mathrm{V}^{3+}+\mathrm{e}^{-}
\end{aligned}
$$

$$
\mathrm{VO}_{2}{ }^{+}+2 \mathrm{H}^{+}+\mathrm{V}^{2+} \underset{\text { charge }}{\stackrel{\text { discharge }}{\longrightarrow}} \mathrm{VO}^{2+}+\mathrm{H}_{2} \mathrm{O}+\mathrm{V}^{3+}
$$

Neglecting the electrolyte mixing time required in the cell and the tank, assuming that an identical mechanism is shared by an charge and discharge cycles, and the electrolyte flow rate is maintained constant, the rate of the concentration change in $\mathrm{V}^{2+}$ is related to the battery current $i$ by

$$
\frac{\mathrm{d}\left[\mathrm{V}^{2+}\right]_{\mathrm{C}}}{\mathrm{d} t}=\mp \frac{i}{\alpha_{C} F}+\frac{Q}{\alpha_{C}}\left\{\left[\mathrm{~V}^{2+}\right]_{\mathrm{T}}-\left[\mathrm{V}^{2+}\right]_{\mathrm{C}}\right\}
$$

where $\alpha_{C}$ represents the electrolyte amount in a VRB, $F$ the faraday constant, $i(+/-)$ the current during discharge/charge processes. The total amount of vanadium ions $\mathrm{V}^{2+}$ in both the cell and the tank satisfy

$$
\alpha_{\mathrm{C}}\left[\mathrm{V}^{2+}\right]_{\mathrm{C}}+\alpha_{\mathrm{T}}\left[\mathrm{V}^{2+}\right]_{\mathrm{T}}=\frac{N}{N_{A}}
$$

where $\alpha_{T}$ symbolizes the amount of electrolyte held in the tank, $N$ the number of $\mathrm{V}^{2+}, N_{A}$ the Avagadro constant. The rate of change of $N$ is related to the current $i$ by

$$
\frac{1}{N_{A}} \frac{\mathrm{d} N}{\mathrm{~d} t}=\mp \frac{i}{F}
$$

According to Eqs. (21) to (23), the concentration change in $\mathrm{V}^{2+}$ is represented as

$$
\begin{aligned}
\frac{\mathrm{d}^{2}\left[\mathrm{~V}^{2+}\right]_{\mathrm{C}}}{\mathrm{d} t^{2}}= & -\left\{Q\left(\frac{1}{\alpha_{\mathrm{C}}}+\frac{1}{\alpha_{\mathrm{T}}}\right)-\frac{1}{Q} \frac{\mathrm{d} Q}{\mathrm{~d} t}\right\} \frac{\mathrm{d}\left[\mathrm{V}^{2+}\right]_{\mathrm{C}}}{\mathrm{d} t} \\
& \mp \frac{1}{\alpha_{\mathrm{C}} F} \frac{\mathrm{d} i}{\mathrm{~d} t} \mp\left(\frac{Q}{\alpha_{\mathrm{C}}}-\frac{1}{Q} \frac{\mathrm{d} Q}{\mathrm{~d} t}\right) \frac{i}{\alpha_{\mathrm{C}} F}
\end{aligned}
$$

Provided that the flow rate $Q$ is held constant at $Q_{0}$, Eq. (24) is then simplified into

$$
\begin{aligned}
\frac{\mathrm{d}^{2}\left[\mathrm{~V}^{2+}\right]_{\mathrm{C}}}{\mathrm{d} t^{2}}= & -Q_{0}\left(\frac{1}{\alpha_{\mathrm{C}}}+\frac{1}{\alpha_{\mathrm{T}}}\right) \frac{\mathrm{d}\left[\mathrm{V}^{2+}\right]_{\mathrm{C}}}{\mathrm{d} t} \mp \frac{1}{\alpha_{\mathrm{C}} F} \frac{\mathrm{d} i}{\mathrm{~d} t} \\
& \mp \frac{Q}{\alpha_{\mathrm{C}}} \frac{i}{\alpha_{\mathrm{C}} F}
\end{aligned}
$$

while the change in the $\mathrm{V}^{2+}$ concentration in the tank is expressed as

$$
\frac{\mathrm{d}\left[\mathrm{V}^{2+}\right]_{\mathrm{T}}}{\mathrm{d} t}=\frac{1}{\alpha_{\mathrm{T}}}\left(-\alpha_{\mathrm{C}} \frac{\mathrm{d}\left[\mathrm{V}^{2+}\right]_{\mathrm{C}}}{\mathrm{d} t} \mp \frac{i}{F}\right)
$$

Through the Nernst equation, the equilibrium potential of a VRB is found subject to the electrolyte concentration [20]. Given the concentrations of both the vanadium and hydrogen ions in the cell stack of a VRB, the equilibrium potential $V_{e q}$ is evaluated as

$$
E=E^{\prime}+\frac{R T}{F} \ln \frac{\left[\mathrm{V}^{2+}\right]_{\mathrm{C}}\left[\mathrm{VO}_{2}^{+}\right]_{\mathrm{C}}\left[\mathrm{H}^{+}\right]_{\mathrm{C}}\left[\mathrm{H}^{+}\right]_{\mathrm{C}}}{\left[\mathrm{V}^{3+}\right]_{\mathrm{C}}\left[\mathrm{VO}^{2+}\right]_{\mathrm{C}}}
$$


where $E^{\prime} \fallingdotseq 1.255 \mathrm{~V}$ denotes standard potential, a quantity derived form the reduction potential of two redox couples, $R$ the ideal gas constant, and $T$ the temperature.

Accordingly, $\left[\mathrm{VO}_{2}{ }^{+}\right]$, the concentrations of $\mathrm{VO}_{2}{ }^{+}$is made equal to $\left[\mathrm{V}^{2+}\right]$ in a fully charged state, following which $\left[\mathrm{VO}_{2}{ }^{+}\right]$ $=\left[\mathrm{V}^{2+}\right]$ and $\left[\mathrm{VO}^{2+}\right]=\left[\mathrm{V}^{3+}\right]$ at any given state of charge, and Eq. (27) is simplified into

$$
E=E^{\prime}+\frac{R T}{F} \ln \frac{\left[\mathrm{V}^{2+}\right]_{\mathrm{C}}^{2}\left[\mathrm{H}^{+}\right]_{\mathrm{C}}^{2}}{\left[\mathrm{~V}^{3+}\right]_{\mathrm{C}}^{2}}
$$

According to the (24) and (28), a vanadium redox flow battery model is developed by Simulink, which is show in Fig. 11.

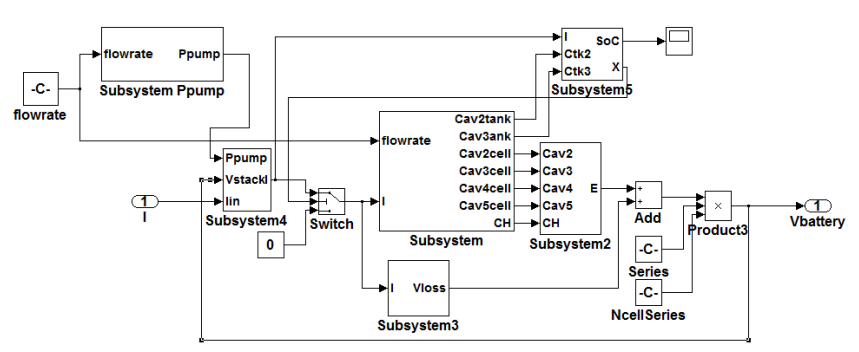

Fig. 11. VRB subsystem model.

\section{SYSTEM DESCRIPTION}

The renewable energy based hybrid power system model in Simulink is shown in Fig. 12. The system consists of a $250 \mathrm{~W}$ solar cell, a $600 \mathrm{~W}$ wind turbine, a $5 \mathrm{HP}$ hydro turbine, a $100 \mathrm{~W}$ proton exchange membrane fuel cell, a $1 \mathrm{kWh}$ vanadium redox flow battery, an ultra-capacitors, an electrolyzer, and a power conditioner. The power conditioner includes a boost circuit and a SPWM inverter. It is used to step up ultra-capacitor voltage to DC $200 \mathrm{~V}$ and invert to $120 \mathrm{~V}_{\mathrm{rms}}, 60 \mathrm{~Hz}$ AC. The power conditioner subsystem components are shown in Fig. 13 [8], [21], [22]. The wind turbine adopted is TIMAR Wind Energy. When wind speed is $12 \mathrm{~m} / \mathrm{s}$, the wind turbine produces the maximum power $600 \mathrm{~W}$. Solar cell adopted is Topper Sun Energy TS-M250 and its maximum power is $250 \mathrm{~W}$. Hydro turbine adopted is New Energy Corporation ENC-005-F4, in here we changed the generator that nominal power from $5 \mathrm{~kW}$ to $5 \mathrm{HP}$. Wind turbine, hydro turbine, and solar cell are the main sources to supply load demand. The vanadium redox flow battery is an energy storage device in the system. Fuel cell model includes a fuel cell module and a fuel controller. The fuel cell is an accessory generator in this system. In order to keep the supply and demand is balanced. When the supply is bigger than the load need, first store the energy by VRB, and when the VRB is fully charged, then use the fuel cell to save the energy. When supply is smaller than the load need, first the VRB discharge to supply the load need, and the fuel cell generation when the VRB reached the discharge limit. Thus, the system can circulate supply load demand and the energy will not be wasted. The flowchart of the energy dispatch strategy is depicted in Fig. 14.

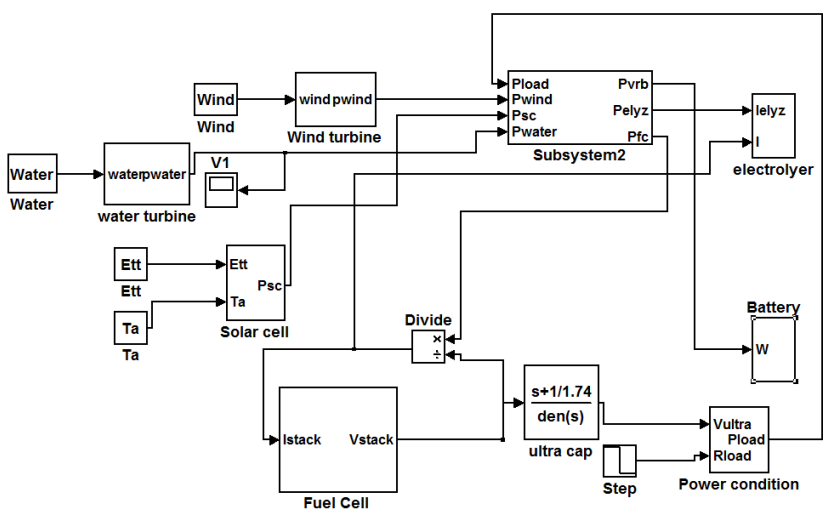

Fig. 12. Hybrid power generation system model.

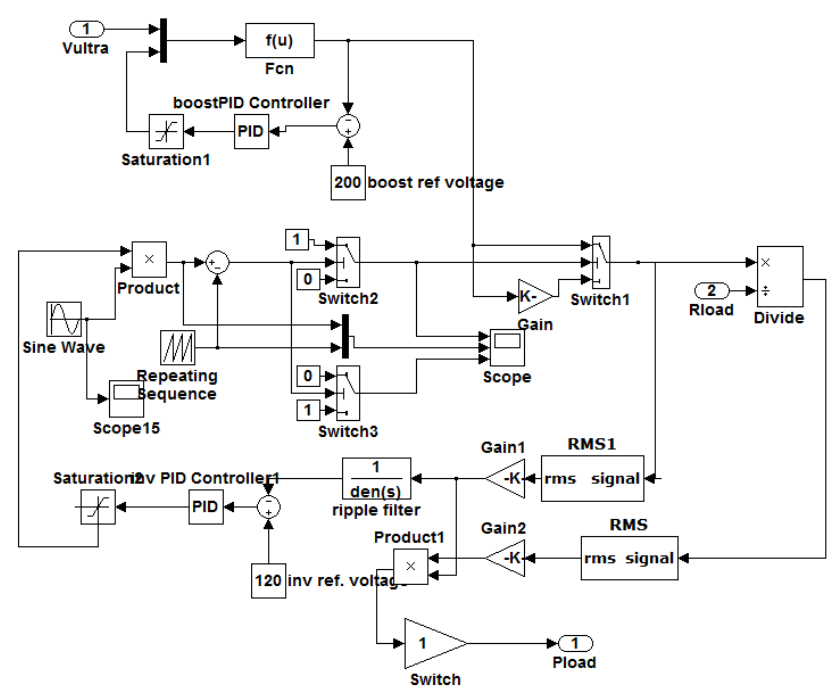

Fig. 13. Power conditioner subsystem model.

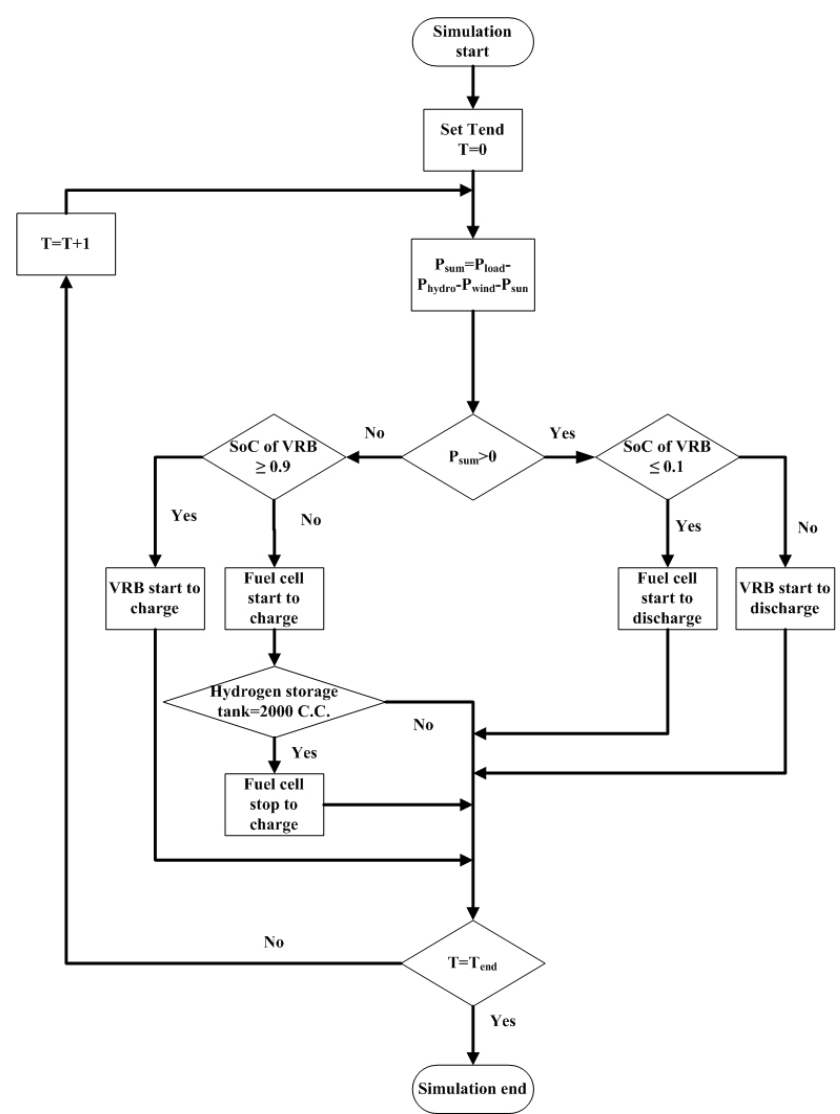

Fig. 14. The flowchart of the energy dispatch strategy. 


\section{Simulation Results}

Simulation results with step changes in load demand, wind speed, water speed, radiation, and ambient temperature are analyzed and shown in Figs. 15-19. Wind speed increases, at $\mathrm{t}=10 \mathrm{~s}$, from 8 to $10 \mathrm{~m} / \mathrm{s}$ and decreases to $5 \mathrm{~m} / \mathrm{s}$ at $\mathrm{t}=16 \mathrm{~s}$. The solar cell initially supplies power at the radiation $400 \mathrm{~W} / \mathrm{m}^{2}$ and temperature $25^{\circ}$. At $15 \mathrm{~s}$, the radiation increases to $600 \mathrm{~W} / \mathrm{m}^{2}$ and temperature also increases to $30^{\circ}$. Water speed increase, at $\mathrm{t}=12 \mathrm{~s}$, from $0.8 \mathrm{~m} / \mathrm{s}$ to $1.1 \mathrm{~m} / \mathrm{s}$. The initial SoC (state of charge) of VRB is 0.1 . These step inputs cause changes in available power and load consumption. The power tracking performance of the hybrid topology with respect to load demand change and environmental variations is shown in Fig. 15.

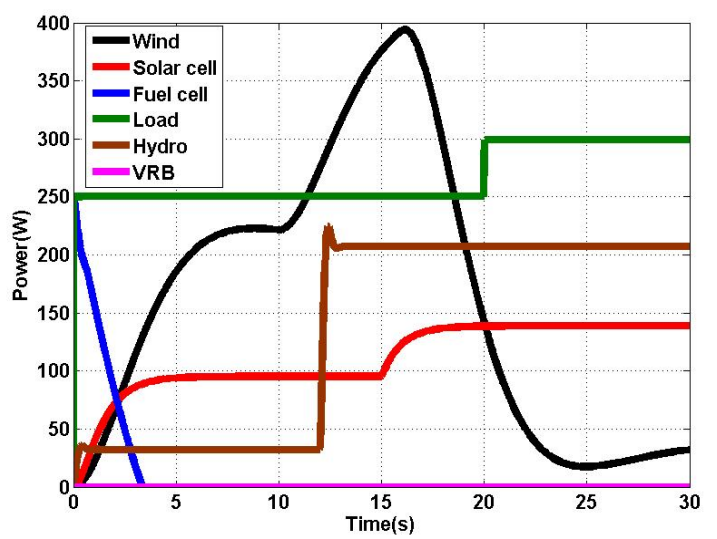

Fig. 15. Power tracking performance of the hybrid power generation system.

With variation in load, the power demand changes from $250 \mathrm{~W}$ to $300 \mathrm{~W}$ at $20 \mathrm{~s}$ as shown in Fig. 15. The fuel cell provides power for load requirement because of the output powers of the wind turbine, hydro turbine and solar cell are not sufficient enough to supply load demand at $\mathrm{t}=0 \mathrm{~s}$ to $3.3 \mathrm{~s}$ when the SoC of VRB is 0.1 (reached the discharge limit). However, as the wind speed and water speed increases, the captured power increases and the contribution of the fuel cell decreases. Any excess power is diverted to the VRB during this period.

The current variations of the solar cell, the fuel cell, and the vanadium redox battery with load changes and environmental conditions are shown in Fig. 16. These changes are reflected in the performance of the fuel cell system and vanadium redox battery. The stack current variation at $\mathrm{t}=0 \mathrm{~s}$ to $3.3 \mathrm{~s}$ is due to start-up transients and load demand, as the solar cell's, hydro turbine's and wind turbine's contributions are limited and fixed. During $\mathrm{t}=3.3 \mathrm{~s}$ to $t=25 \mathrm{~s}$, the fuel cell current decreases to zero because load demand is reduced and the wind turbine increases output power, then the VRB current increases because it is first in order to do the stored energy. After $\mathrm{t}=20 \mathrm{~s}$, variation in $\mathrm{VRB}$ current is due to changes in power demand from the solar cell and hydro turbine with varying availability of wind energy. Thus, it can be seen that the solar cell and hydro turbine to complement part of the wind turbine.

Such changes in fuel cell current cause the stack voltage to vary significantly. Generally, a lower level of current implies higher stack voltage and vice versa. The use of an ultra-capacitor in parallel with the fuel cell reduces the stack's output variation as shown in Fig. 17. However it can be observed the voltage of VRB has slight variations for the charge current changed.

The hydrogen is a fuel of fuel cell. At $t=0 \mathrm{~s}$ to $\mathrm{t}=3.3 \mathrm{~s}$, the fuel cell generated electricity by hydrogen in storage tank. The variation of hydrogen in storage tank is shown in Fig. 18.

Shown in Fig. 19 is the SoC variation of VRB. At $\mathrm{t}=3.3 \mathrm{~s}$, the VRB has charge current, but the SoC of VRB hadn't any variation. Because the VRB system had a pump that used for circulating the electrolyte, so it will consume power when charging and discharging. In this system, the pump power is $57 \mathrm{~W}$. At $\mathrm{t}=5 \mathrm{~s}$, the VRB start to charge when the exceed power bigger than $57 \mathrm{~W}$ and the SoC of VRB had a relatively large varies at $\mathrm{t}=10$ to 20 for wind turbine generated more power. Thus, the system can circulate supply load demand and renewable energy will not be wasted.

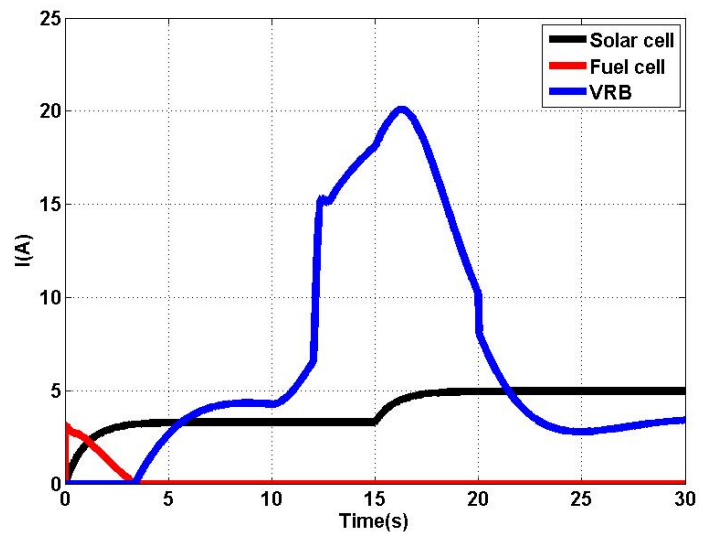

Fig. 16. Current variations.

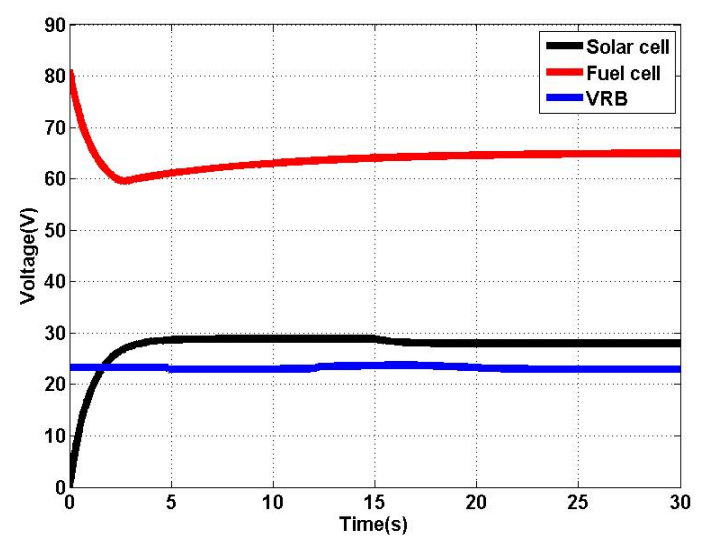

Fig. 17. Voltage variations.

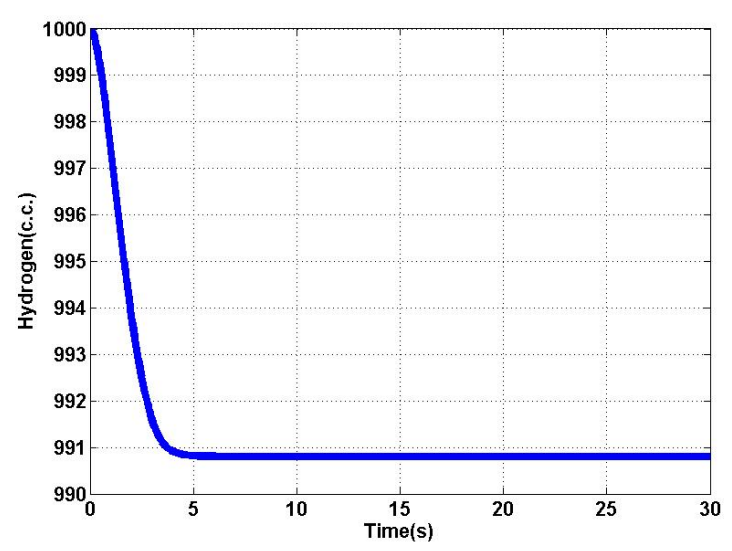

Fig. 18. Hydrogen variation in storage tank. 


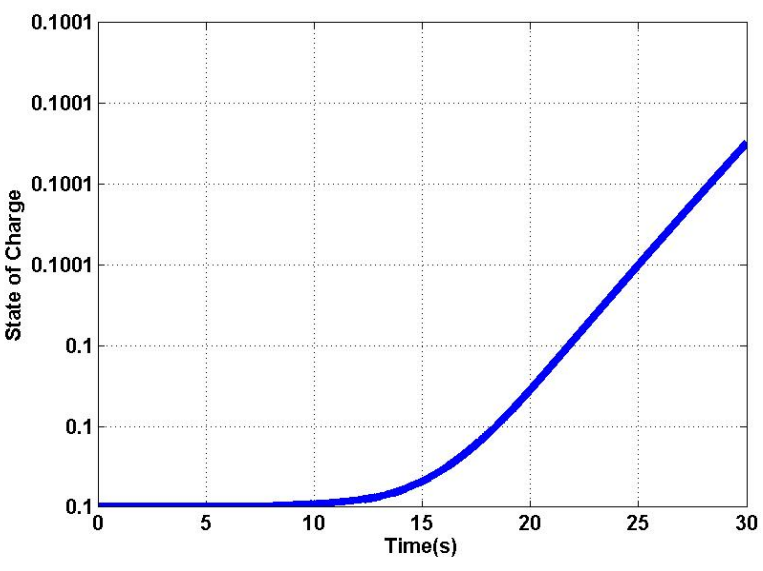

Fig. 19. SoC variation of VRB.

\section{CONCLUSION}

In this paper, a renewable energy based hybrid power generation systems and modeled for a stand-alone user with appropriate power controllers is proposed. The available power from the renewable energy sources is highly dependent on environmental conditions such as wind speed, water speed, radiation, and ambient temperature. To overcome this deficiency of the solar cell, hydro and wind system, we integrated them with the FC and VRB system using a novel topology. The voltage variation at the output is found to be within the acceptable range. The output fluctuations of the wind turbine varying with wind speed, hydro turbine with water speed and the solar cell varying with both environmental temperature and sun radiation are reduced using a fuel cell and vanadium redox flow battery. Therefore, this system can tolerate the rapid changes in load and environmental conditions, and suppress the effects of these fluctuations on the equipment side voltage. This hybrid topology exhibits excellent performance under variable radiation, ambient temperature, wind speed, water speed and load power requirements. The proposed system can be used for off-grid power generation in non-interconnected areas or remote isolated communities.

\section{REFERENCES}

[1] K. Kobayashi, H. Matsuo, and Y. Sekine, "An excellent operating point tracker of the solar-cell power supply system," IEEE Transactions on Industrial Electronics, vol. 53, pp. 495-499, Apr. 2006.

[2] S. P. Adhau1, R. M. Moharil, and P. G. Adhau, "Reassessment of irrigation potential for micro hydro power generation," in Proc. IEEE International Conference on Sustainable Energy Technologies (ICSET), Kandy, Sri Lanka, pp. 1-5, Dec. 2010.

[3] Y. Z. Lee, "Agriculture water resources for effective renewable generation," Department of Irrigation Management Technology Council of Agriculture Taiwan Joint Irrigation Association, Harvest vol. 60, no. 11, July 2010.

[4] C. T. Pan, J. Y. Chen, C. P. Chu, and Y. S. Huang, "A fast maximum power point tracing for photovoltaic power systems," in Proc. IEEE Industrial Electronics Society Conference, vol. 1, pp. 390-393, 1999.

[5] W. H. Wang and X. D. Wang, "Analysis and Measurement of SOC in the Vanadium Flow Batter," Journal of Zhejiang University of Technology, vol. 34, Apr. 2006.

[6] J. A. Gow and C. D. Manning, "Development of a photovoltaic array model for use in power-electronics simulation studies," in IEE Proc. Electric Power Application, pp. 193-200, Mar. 1999.
[7] M. J. Khan and M. T. Iqbal, "Dynamic modeling and simulation of a small wind-fuel cell hybrid energy system," Renewable Energy, pp. 421-439, 2005.

[8] S. M. Shaahid and M. A. Elhadidy, "Technical and economic assessment of gidindependent hybrid photovoltaic-diesel-battery power systems for commercial loads in desert environments," Renewable and Sustainable Energy Reviews, pp. 1794-1810, Oct. 2007.

[9] D. B. Nelson, M. H. Nehrir, and C. Wang, "Unit sizing and cost Analysis of stand-alone hybrid wind/PV/fuel cell power generation systems," Renewable Energy, pp. 1641-1656, Aug. 2006.

[10] B. C. Kuo, Automatic Control Systems, 7thed. New York: Prentice Hall Inc, 1995.

[11] S. E. Ben Elghali1, M. E. H. Benbouzid1, and J. F. Charpentier, "Modelling and control of a marine current turbine-driven doubly fed induction generator," IET Renewable Power Generation, vol. 4, pp. $1-11,2010$

[12] M. J. Khan, M. T. Iqbal, and J. E. Quaicoe "Dynamics of a vertical axis hydrokinetic energy conversion system with a rectifier coupled multi-pole permanent magnet generator," IET Renewable Power Generation, vol. 4, pp. 116-127, 2010.

[13] B. Delfino and F. Fornari, "Modeling and control of an integrated fuel cell-wind turbine system," in Proc. IEEE Bologna PowerTech Conference, pp. 23-26, 2003

[14] S. Obara, "Analysis of a fuel cell micro-grid with a small-scale wind turbine generator," International Journal of Hydrogen Energy, vol. 32, pp. 323-336, March 2007.

[15] J. C. Amphlett, R. M. Baumert, R. F. Mann,B. A. Peppley, P. R. Roberge, and T. J. Harries, "Performance modeling of the ballard mark-IV solid polymer electrolyte fuel cell," Journal of the Electrochemical Society, vol. 1, pp. 9-15, 1995.

[16] A. Rowe and $\mathrm{X}$. Li, "Mathematical modeling of proton exchange membrane fuel cells," Journal of Power Sources, vol. 102, pp. 82-96, Dec. 2001

[17] O. Ulleberg, "Stand-alone power systems for the future: Optimal design, operation and control of solar-hydrogen energy systems," Ph.D. Dissertation, Norwegian University of Science and Technology, 1997.

[18] K. Sapru, N. T. Stetson, and S. R. Ovshinsky, "Development of a small scale hydrogen production storage system for hydrogen applications," in Proc. the 32 $2^{\text {nd }}$ Intersociety Conference, vol. 3, pp. 1947-1952, 1997.

[19] C. Blanc and A. Rufer, "Optimization of the operating point of a vanadium redox flow battery," IEEE Energy Conversion Congress and Exposition (ECCE2009), pp. 2600-2605, Sep. 2009.

[20] M. H. Li and T. Hikihara, "A coupled dynamical model of redox flow battery base on chemical reaction, fluid flow, and electical circuit," Ieice. Fundamentals, vol. E91-A, no. 7, July 2008.

[21] B. Ismail, S. Taib, A. R. Saad, M. Isa, and C. M. Hadzer, "Development of a single phase SPWM microcontroller-based inverter," in Proc. 2006 IEEE Power and Energy Conference, pp. 437-440, March 2006.

[22] W. X. Lin, "A new approach to the harmonic analysis of SPWM waves," in Proc. IEEE Mechatronics and Automation Conference, pp. 390-394, 2006.

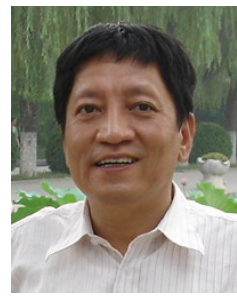

Hung-Cheng Chen received both the M. S. and Ph.D. degrees in Electrical Engineering from National Taiwan University of Science and Technology in 1989 and 1993, respectively. He is currently an associate professor in the Department of Electrical Engineering, National Chin-Yi University of Technology, Taiwan. His research interests include renewable energy systems, micro grid control, and partial discharge diagnosis.

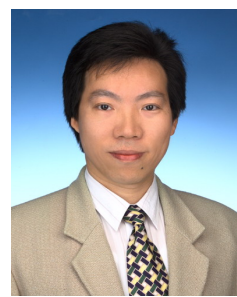

Po-Hung Chen was born on April 21, 1963, in Taipei, Taiwan. He received the B.S. degree from the National Taiwan University of Science and Technology (NTUST), Taipei, the M.S. degree from the National Tsing Hua University, Hsinchu, Taiwan, and the Ph.D. degree from the NTUST, in 1986, 1989, and 1997 , respectively, all in electrical engineering. Since 1989, he has been with the St. John's University, Taipei, where he is currently a professor in the Department of Electrical Engineering. His current research interests include power system planning, partial discharge measurement, and renewable generation techniques. 